\title{
Pencitraan Inframerah Dekat dari Lemak Sapi pada Model Lemak Tissue
}

\author{
Chrisli Elfri Sahuleka, ${ }^{1}$ Jodelin Muninggar, ${ }^{1}$ dan Ferdy S. Rondonuwu*1,2 \\ ${ }^{1}$ Fisika, Fakultas Sains Dan Matematika, Universitas Kristen Satya Wacana, Jl. Diponegoro 52-60, Salatiga 50711 \\ ${ }^{2}$ Pusat Studi Aplikasi NIR, Universitas Kristen Satya Wacana, Jl. Diponegoro 52-60, Salatiga 50711
}

Intisari

\begin{abstract}
Kecantikan mejadi perhatian bagi semua wanita. Beberapa cara yang dilakukan untuk memperoleh kecantikan dengan pemakaian krim, perawatan rutin di klinik kecantikan sampai dengan tindakan operasi plastik dengan menyedot lemak pada bagian wajah yang diinginkan. Pada tahap awal operasi pelastik, dilakukan pengirisan 2-4 $\mathrm{cm}$ pada kulit sebelum menyedot lemak keluar. Pengirisan ini dapat menyebabkan berbagai resiko. Oleh karena itu, suatu metode non-destruktif diperlukan untuk mengidentifikasi posisi lemak sebagai tahap pra-operasi plastik. Spektroskopi inframerah dekat adalah suatu metode untuk mengidentifikasi dan mengukur secara cepat dan tepat tanpa merusak sampel.Tujuan penelitian ini untuk mengidentifikasi daerah spektra dan atau panjang gelombang yang sensitif terhadap lemakdan beberapa komponen penting lainnya serta menentukan posisi lemak dengan melihat citra satu dimensi. Sampel terbuat dari lemak dan daging sapi yang disusun sedemikian rupa dan dipindai. Pada spektrum hasil pemindaian dilakukan beberapa tahapan pra-analisis. Hasil penelitian menunjukan letak lemak terdapat pada posisi 11-28. Dari hasil penelitian dapat disimpulkan bahwa NIRS dapat menginformasikan posisi lemak dari citra satu dimensi.
\end{abstract}

\section{Abstract}

All women concern for their beauty. Some ways are done to obtain beauty with the use of creams, routine care in beauty clinics, up to plastic surgery by having liposuction on the desired part of the face. In the early procedures of plastic surgery, a 2-4 cm incision is made on the skin before sucking the fat out. This cutting can cause various risks. Therefore, a non-destructive method is needed to identify the position of fat as a pre-plastic surgery procedure. Near Infrared Spectroscopy is a method for quickly and precisely identifying and measuring a sample without damaging it. This study aims to determine the area spectral and or wavelength sensitivity for fat and several other important components and to determinethe position of fatfrom a one-dimensional image.The results show that the location of fat is in position 11-28. From this, it can be concluded that NIRS can inform the position of fat from a one-dimensional image.

Keywords: beauty; fat; image; Near Infrared Spectroscopy (NIRS).

*Corresponding author: ferdy.rondonuwu@uksw.edu

http://dx.doi.org/10.12962/j24604682.v15i3.4584

2460-4682 (C)Departemen Fisika, FSains-ITS

\section{PENDAHULUAN}

Kecantikan menjadi perhatian utama para wanita sejak dulu sampai saat ini. Bukan hanya pada kalangan remaja dan dewasa saja, tidak jarang pada beberapa wanita dengan usia lanjut juga tidak mau ketinggalan untuk menjaga kecantikannya. Beberapa upaya yang dapat dilakukan untuk memperoleh kecantikan diantaranya dengan penggunaan krim secara rutin ataupun melakukan perawatan pada klinik-klinik kecantikan. Disisi lain upaya yang terus dilakukan untuk memaksimalkan kecantikan salah satunya melalui operasi plastik. Belakangan operasi pelastik menjadi salah satu pilihan yang sering dipilih untuk mendapatkan kecantikan sesuai yang diinginkan. Data International Society of Aesthetic Plastic Surgery tahun 2016 menunjukkan bahwa facial liposuction (14\%) menjadi prosedur operasi terpopuler yang diikuti dengan operasi kelopak mata $(12,9 \%)$, operasi hidung $(7,6 \%)$, dan operasi pada area perut $(7,4 \%)$ [1]. Semua operasi ini diawali dengan prosedur pengirisan 2-4 $\mathrm{cm}$ pada kulit kemudian dimasukkan tabung tipis yang disebut kanula, yang dipindahkan bolak-balik untuk memecah lemak yang kemudian lemak itu akan disedot. Pengirisan bersifat destruktif dan cenderung dapat menyebabkan komplikasi dan resiko seperti bekas luka permanen, cedera saraf wajah, dan hematoma [2]. Oleh karena itu, suatu metode non-destruktif yang akurat dan langsung diperlukan untuk mengidentifikasi letak lemak sebagai tahap pra-operasi kecantikan.

Beberapa tahun belakangan ini, spektroskopi inframerah dekat telah banyak dikembangkan untuk mengidentifikasi dan mengukur secara cepat dan tepat tanpa merusak sampel. Pada bidang pertanian dan peternakan, NIRS digunakan untuk menganalisis komposisi kelembaban dari minyak segar, 


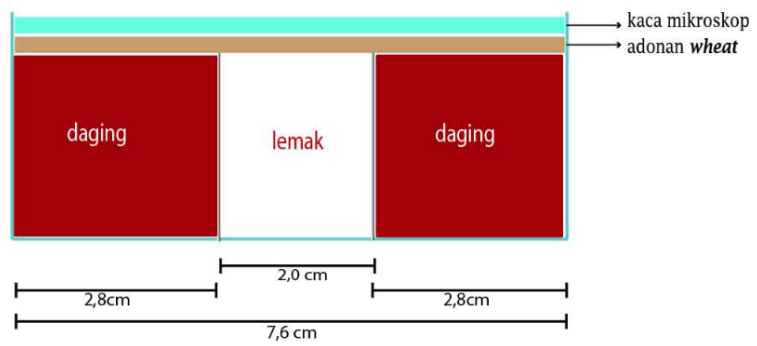

Gambar 1: Hasil preparasi sampel.

minyak kering dan asam lemak utama pada tanaman zaitun [3] dan identifikasi jenis otot lembu [4]. NIR juga digunakan sebagai pedeteksi kadar flavonoid pada ekstrak daun tanaman dalam bidang farmasi [5]. Selain itu, dalam bidang kesehatan dan kedokteran NIR digunakan untuk mendeteksi kondisi janin melalui metode jaringan syaraf tiruan [6]. Dengan beberapa hasil penelitian ini NIRS semakin meyakinkan untuk digunakan sebagai alat untuk mendeteksi kandungan dan kadar dari spektrum sebuah sampel.

NIRS dengan menggunakan panjang gelombang elektromagnetik mendekati daerah kerjayaitu sekitar 800-2500 nm atau 12.500-4.000 $\mathrm{cm}^{-1}$. Spektrum NIR akan membawa informasi tentang serapan-serapan spesifik senyawa organik melalui karakteristik vibrasi. Terbukti selama tiga dekade belakangan NIRS menjadi salah satu alat paling canggih dan efisien dalam melihat susunan dan kualitas dalam daging maupun produk daging [7, 8] memetakan limfatik intraoperatif dan [9] memetakan distribusi lemak pada filet ikan salmon, dan menunjukkan daerah serapan spektra serupa yaitu antara 899-1700 nm diperlukan untuk menginformasikan lemak. Jaringan lemak pada kulit manusia melibatkan ikatan senyawa organik ester (R-COOR). Dengan melihat serapan gugus fungsi ester, ikatan lemak di bawah kulit dapat terdeteksi dan dipetakan.Dengan prinsip ini, maka NIRS seharusnya dapat dikembangkan sebagai pendeteksi untuk memetakan disrtibusi lemak di bawah kulit sebagai tahap praoperasi estetik yang bersifat non-destruktif.

Teknik NIRS ini kemudian disempurnakan menggunakan metode pencitraan hiperspektra. Dengan memindai seluruh permukaan buah apel, [10] memperoleh gambaran lengkap tiga dimensi pencitraan hiperspektra hingga dapat mendeteksi ruam baru dan lama dari apel secara optimal. Hal lain yang juga dilakukan yaitu mendeteksi memar pada mentimun acar [11] dengan menangkap gambar hiperspektral dari mentimun di wilayah spectral 900-1700 nm. Di sisi lain, potensi teknologi pencitraan hiperspektra pada daerah NIR untuk memetakan lemak di bawah kulit belum dieksplorasi. Perlu dipelajari terlebih dahulu bentuk pencitraan 1 dimensi dari lemak di bawah kulit sebagai acuan penelitian lanjutan.

Jaringan saraf tiruan (JST) memungkinkan untuk memodelkan sampel yang menyerupai susunan kulit manusia. Untuk meningkatkan kemampuan NIR dalam memprediksi karakteristik dari sampel, perlu ketelitian lebih pada proses preparasi sampel [7]. Sampel yang dipindai NIRS kemudian menghasilkan data matriks yang dikonversi untuk menghasilkan

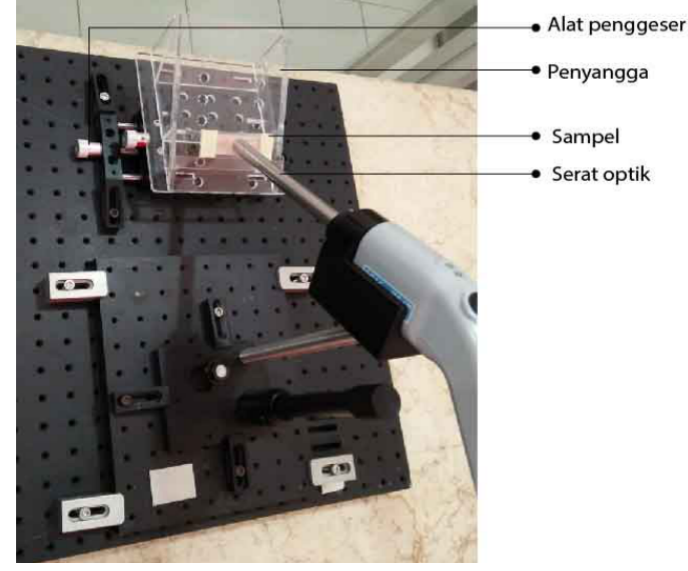

Gambar 2: Sistem pengambilan data.

grafik spektrum. Kemudian pada grafik spektrum dilakukan beberapa tahapanawal sebelum dianalisis. Dari hasil perlakuan tersebut, akan menunjukan grafik spektrum dan citra dari sampel yang selanjutnya digunakan sebagai dasar penentuan posisi lemak pada sampel. Tujuan penelitian ini antara lain mengidentifikasi daerah spektra dan atau panjang gelombang yang sensitif terhadap lemakdan beberapa komponen penting lainnya serta menentukan posisi lemakdari sampel dengan melihat citra satu dimensi.

\section{METODOLOGI}

\section{Preparasi sampel}

Sampel yang dipindai terdiri dari daging dan lemak sapi serta adonan whead. Sampel disusun ke dalam kotak persegi panjang yang terbuat dari akrilik dengan panjang dan lebarnya 7,6 $\mathrm{cm}$ dan 2,5 cm serta tinggi $1,5 \mathrm{~cm}$. Karena akrilik memiliki serapan inframerah dekat, maka tebal sampel dibuat cukup sehingga dipastikan tidak ada lagi serapan yang disebabkan oleh akrilik dan NIR tidak akan menerobos sampai kepada akrilik. Sampel dengan kandungan daging diletakan pada kedua ujung kotak persegi panjang dengan ukuran panjang 2,8 $\mathrm{cm}$, untuk sampel dengan kandungan lemak diletakan pada bagian tengah dengan ukuran panjang $2,0 \mathrm{~cm}$. Sampel yang sudah disusun ke dalam kotak persegi kemudian ditutupi dengan adonan wheat sesuai dengan ukuran permukaan sampel. Setelah ditutupi adonan whead sampel ditutupi lagi dengan kaca mikroskop kemudian pada pinggiran sampel direkatkan dengan menggunakan perekat dari kertas tujuannya agar kaca mikroskop tidak terjatuh saat dimiringkan pada proses pemindaian, hasil preparasi sampel ditunjukan pada Gambar 1 .

Setelah proses preparasi, sampel diletakan pada alat penyangga tepat dibawah serat optik dimana ini merupakan sensor detektor pada NIR. Pada tahap ini dibutuhkan perhatian lebih karena hasil spektra dari sensor detektor pada pengujian sampel padat tergantung posisi atau sudut penempatannya sehingga memungkinkan radiasi gelombang diterima dengan baik oleh sampel [12]. Selanjutnya pada bagian bawah alat penyangga terdapat alat bantu penggeser. Alat bantu 


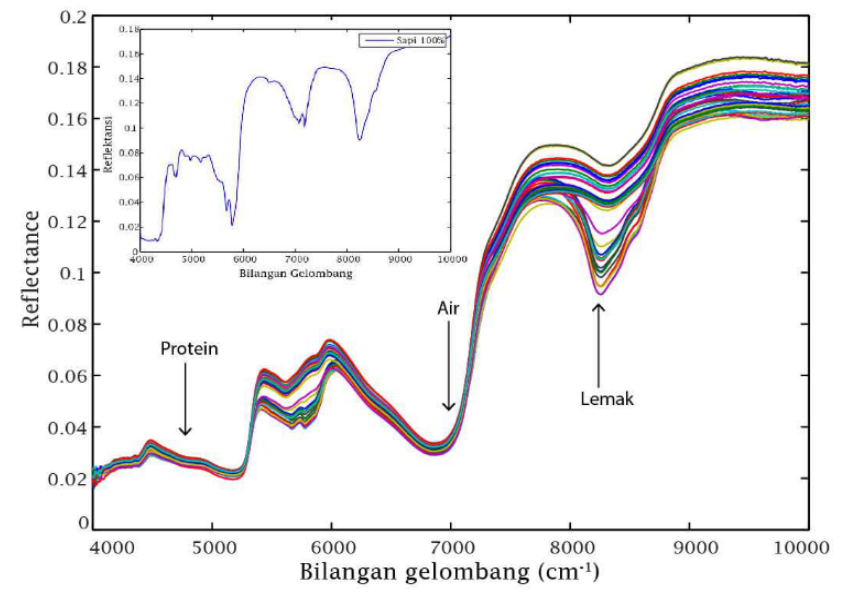

Gambar 3: Spektrum murni sampel dari 39 posisi.

penggeser ini bertugas untuk membantu dalam proses penggeseran sampel ketika proses pengukuran. Setelah sampel diletakkan pada alat penyangga dan penggeser, sampel kemudian dipindai, hal ini ditunjukan pada Gambar 2.

\section{Pengukuran sampel}

Spektrometer inframerah dekat (Buchi Nirfelx 500 solid) yang digunakan pada penelitian ini dihubungkan dengan perangkat kabel serat optik. Pengambilan data spektroskopi NIR dilakukan dengan cara sampel digeser dari kanan ke kiri dengan bantuan alat bantu penggeser. Dalam sekali putaran alat penggeser bergerak tiap 1,5 $\mathrm{mm}$ dan putaran dari awal sampai akhir menghasilkan 39 posisi. Pada setiap posisi diambil data spektroskopinya. Bentang energi yang digunakan pada pengukuran ini yaitu $4.000-10.000 \mathrm{~cm}^{-1}$ dengan interval $4 \mathrm{~cm}^{-1}$.

\section{Analisis data}

Data matriks dari 39 posisi yang diperoleh dari hasil pemindaian menggunakan NIRS kemudian diolah dengan melakukan beberapa langkah awal sebelum menganalisis data diantaranya normalisasi dan smoothing sampai dengan menampilkan citra satu dimensi dengan menggunakan Matlab. Smoothing bertujuan untuk menghilangkan noise pada frekuensi tinggi dari grafik dan meningkatkan daya pisah setiap puncak serapan [13]. Sedangkan normalisasi berfungsi untuk meminimalkan perbedaan spektrum akibat akibat pergeseran baseline dan hamburan multiplikasi [14]. Setelah melakukan beberapa langkah tersebut spektrum yang sudah dinormalisasi dan smoothing serta citra satu dimensi dijadikan sebagai acuan dalam menganalisis posisi lemak dibawah kulit.

\section{HASIL DAN PEMBAHASAN}

Berikut ditampilkan grafik spektrum murni hasil pemindaian NIRS terhadap sampel dari 39 posisi dimana pada spektrum ini belum dilakukan beberapa tahapan pra-analisis.

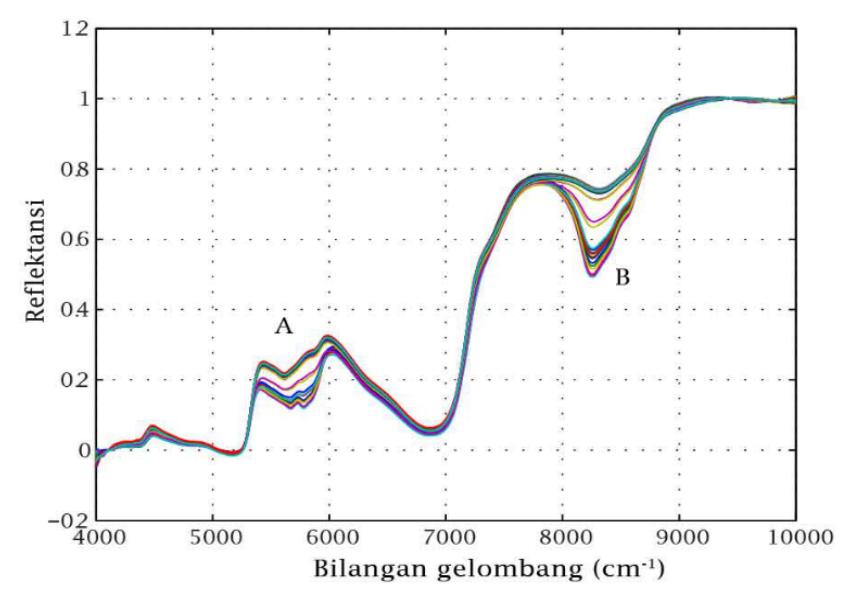

Gambar 4: Spektrum hasil normalisasi dan smoothing.

Gambar 3 menunjukan spektrum murni hasil pemindaian dari 39 posisi. Pada spektrum ini terlihat beberapa komponenkomponen penting yang terdapat didalamnya. Komponen air dimana pada prinsipnya daging yang diukur mengandung air yang terlihat pada daerah bilangan gelombang $7067 \mathrm{~cm}^{-1}$ dimana dijelaskan lebih khusus oleh [7] bahwa pada daerah panjang gelombang $1415 \mathrm{~nm}$ atau setara dengan energi pada bilangan gelombang $7067 \mathrm{~cm}^{-1}$ merupakan pengelompokan karakteristik untuk air, sedangkan untuk protein ditunjukan pada daerah bilangan gelombang $4578 \mathrm{~cm}^{-1}$, hal ini juga sudah dijelaskan terlebih dahulu oleh [15] bahwa serapan protein terdapat pada panjang gelombang 2061 dan $2184 \mathrm{~nm}$ atau 4852 dan $4578 \mathrm{~cm}^{-1}$. Selain itu komponen lemak juga terlihat muncul pada daerah bilangan gelombang $8280 \mathrm{~cm}^{-1}$ hal ini juga dapat disesuaikan dari gambar spektrum lemak yang disandingkan pada Gambar 3. Jika diperhatikan grafik spektrum murni ini memiliki beberapa persoalan diantaranya bentuk pola spektrum memiliki kemiripan antara satu dan lainnya, selain itu baseline dan intensitas dari setiap spektrum berubahubah, hal ini diakibatkan oleh paparan radiasi dan distribusi partikel yang diterima oleh sampel [16]. Untuk mengatasi beberapa persoalan tersebut, spektrum murni ini dilakukan beberapa tahapan sebelum dianalisis lebih lanjut yaitu dengan melakukan normalisasi dan smoothing yang hasilnya ditampilkan pada Gambar 4.

Gambar 4 merupakan hasil normalisasi dan smoothing dari spektrum murni untuk menghilangkan noise dan posisi yang tumpang tindih agar tampak lebih jelas perbedaanya dan untuk menghilangkan pengaruh perbedaan ukuran partikel sampel uji [17] sehingga spektrum data sudah dapat dianalisa dengan baik. Pada bagian A dan B yang ditunjukan di Gambar 4 merupakan grafik yang menunjukan adanya perubahan penyerapan pada daerah bilangan gelombang $5348-6050 \mathrm{~cm}^{-1}$ dan $7908-8740 \mathrm{~cm}^{-1}$. Perubahan penyerapan ini bergantung pada perpindahan setiap posisi pada sampel, dan untuk setiap posisi pada sampel menunjukan keberadaan dari daerah daging dan lemak. Dimana jika dibuat tampilan citra permukaan spektrum dalam bentuk tiga dimensi antara reflektansi, bilangan gelombang dan posisi ini terlihat seperti Gambar 5. 


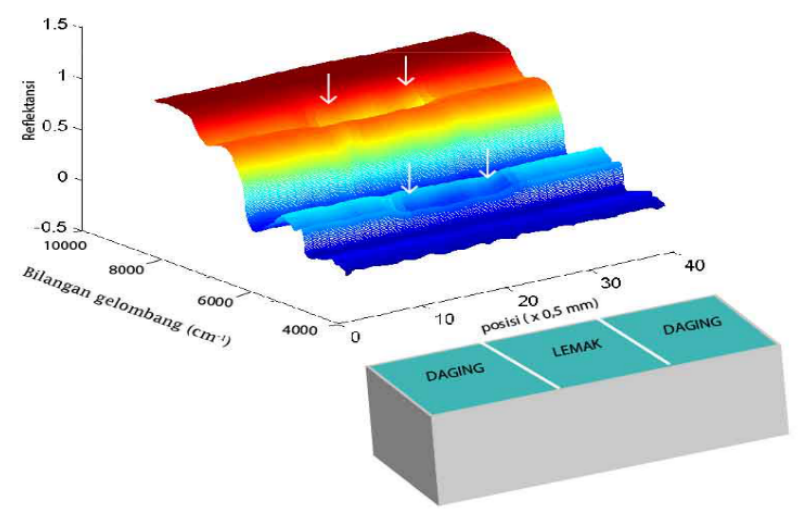

Gambar 5: Spektrum permukaan dalam bentuk tiga dimensi.

Gambar 5 menunjukan citra permukaan spektrum dalam bentuk tiga dimensi, untuk daerah yang ditunjukan dengan tanda panah putih merupakan bagian A dan B pada Gambar 4 yang menunjukan adanya perbedaan penyerapan dimana sudah dijelaskan sebelumnya bahwa perubahan penyerapan ini dikarenakan pergeseran posisi pada sampel sehingga NIR mendeteksi letakdaerah yang terdapat lemak dibawahnya. Oleh sebab itu dari Gambar 5 sudah dapat dilihat bahwa posisi lemak mulai terbaca dari posisi ke 11 dan berakhir pada posisi ke 28. Hal ini dibantu dengan tampilan sampel dengan penjelasan posisi lemak dan daging secara berdamping-an pada Gambar 5. Selain citra 3 dimensi, posisi lemak juga dapat dilihat dengan mengambarkan citra 1 dimensi sepanjang bilangan gelombang $4000-10000 \mathrm{~cm}^{-1}$ dengan interval 4 $\mathrm{cm}^{-1}$. Hal ini bertujuan untuk melihat bahwa pada beberapa citra dengan bilangan gelombang tertentu akan menghasilkan pemetaan pola citra yang flat, sedangkan pada bilang an gelombang tertentu yang terjadi perubahan serapan akan terlihat ada pemetaan pola citra yang terbentuk, dimana hasil citra 1 dimensi ini ditunjukan pada Gambar 6.

Pada Gambar 6(a) ini merupakan pola citra satu dimensi sepanjang bilangan gelombang $4000-10000 \mathrm{~cm}^{-1}$ dengan interval $50 \mathrm{~cm}^{-1}$, yang mengahasilkan 120 pola citra.. Dari pemetaan 120 pola citra ini terdapat beberapa pemetaan pola citra dengan bentuk pola flat yang terlihat saling tumpang tindih dengan serapan yang sedikit berbeda-beda.Namun pada beberapa citra terlihat adanya pola yang terbentuk dengan serapan yang berbeda pada setiap posisi. Hal ini dikarenakan informasi yang disampaikan pada setiap bilangan gelombang menginformasikan kandungan dari sampel untuk setiap posisi dengan serapannya masing-masing, sehingga dengan kandungan bahan sampel yang sama akan menghasilkan pemetaan pola citra yang flat pada setiap posisi, sebaliknya pada kandungan bahan yang berbeda akan ada pola citra yang terbentuk dengan serapan yang berbeda pada setiap posisi. Sebelumnya beberapa algoritma yang telah dikembangkan digunakan untuk pengolahan gambar dengan panjang gelombang yang dianggap paling relevan dipilih untuk memvisualisasikan konsentrasi kimia yang didistribusikan isi [18]. Untuk itu

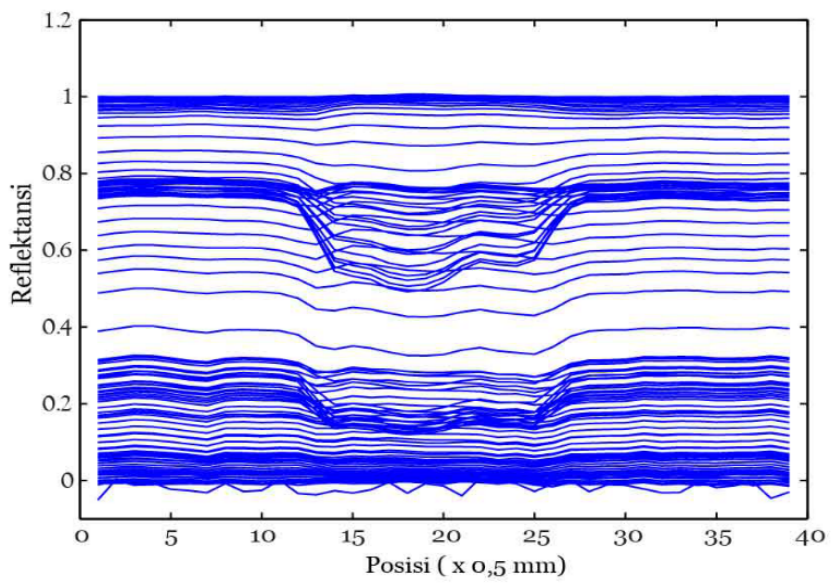

(a) $4000-10000 \mathrm{~cm}^{-1}$

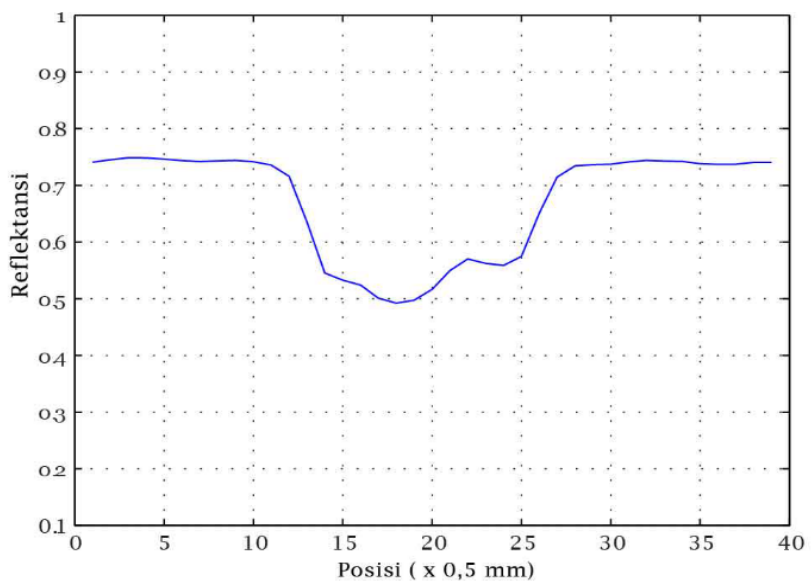

(b) $8250 \mathrm{~cm}^{-1}$

Gambar 6: Model citra satu dimensi pada bilangan gelombang tertentu.

dari 120 pola citra ini dipilih salah satu bilangan gelombang yang di anggap paling baik untuk menunjukan citra satu dimensi lemak pada sampelyang ditunjukan oleh Gambar 6(b). yaitu pada bilangan gelombang $8250 \mathrm{~cm}^{-1}$. Dari citra pada bilangan gelombang $8250 \mathrm{~cm}^{-1}$ ini posisi sampel 1-10 menunjukan perubahan serapan yang cukup konstan dikarenakan pada data ini kandungan sampel hanya daging, kemudian mulai dari posisi sampel 11-14 terjadi perubahan penyerapan dimana perubahan ini diakibatkan karena perubahan kandungan sampel adalah daging dan lemak, kemudian posisi sampel 1525 merupakan letak dari kadungan lemak pada sampel, yang kemudian setelah itu dari posisi 26-28 terjadi perubahan penyerapan lagi dimana hal ini dikarenakan posisi dari lemak mulai menyentuh posisi dari daging sehingga pada data ini kandungannya adalah daging dan lemak, yang kemudian pada data ke 29-39 penyerapan mulai kembali konstan karena pada data ini kandungan sampel sudah kembali pada daging. 


\section{SIMPULAN}

Metode spektroskopi inframerah-dekat (NIRS) dengan beberapa tahap pengolahan spektrum data sebelum proses menganalisasi terbukti dapat menujukan daerah bilangan gelom- bang yang sensitif terhadap beberapa komponen diantaranya air, lemak dan protein yang masing-masing terbaca pada bilangan gelombang 7067, 8280, dan $4578 \mathrm{~cm}^{-1}$, dan NIRS juga dapat menginformasikan posisi lemak pada sampel uji dari citra satu dimensi maupun citra tiga dimensi.
[1] ISAPS, "The International Study On Aesthetic/Cosmetic Procedures Performed In 2016", International Society of Aesthetic Plastic Surgery, USA, 2016.

[2] D. Antell and MD, "Get Gorgeous Now with Facial Liposuction", Your plastic surgery guide, 2008.

[3] U. Saha and D. Jackson, "Analysis of moisture, oil, and fatty acid composition of olives by nearinfrared spectroscopy: development and validation calibration models", J. Sci. Food Agric., vol. 98, no. 5, pp. 18211831, Sep. 2017.

[4] M. Kamruzzaman, G. ElMasry, D.-W. Sun, and P. Allen, ”Application of NIR hyperspectral imaging for discrimination of lamb muscles”, Elsevier, vol. 104, no. 3, pp. 332340, 2011.

[5] H. Lukman, L. Wulandari, and Y. Retnaningtyas, "Penentuan Kadar Flavonoid pada Ekstrak Daun Tanaman Menggunakan Metode NIR dan Kemometrik", E-J. Pustaka Kesehat., vol. 4, pp. 813, 2016.

[6] R. Agustina, "Pendeteksian Kondisi Janin dengaan Near Infrared Spectroscopy yang Dikenal Melalui Metode Jaringan Syaraf Tiruan”, Fakultas Teknik Universitas Indonesia, Depok, 2012.

[7] N. Pierto, R. Roehe, P. Lavin, G. Batten, and S. Andres, "Application of near infrared reflectance spectroscopy to predict meat and meat products quality: A review", Meat Sci., vol. 83, pp. 86175, May 2009.

[8] R.A. Cahill, M. Anderson, L.M. Wang, I. Lindsey, C. Cunningham, and N.J. Mortensen, "Near-infrared (NIR) laparoscopy for intraoperative lymphatic road-mapping and sentinel node identification during definitive surgical resection of early-stage colorectal neoplasia”, Springer Link, vol. 26, no. 1, pp. 197204.

[9] F. Zhu, H. Zhang, Y. Shao, and Y. He, "Mapping of Fat and Moisture Distribution in Atlantic Salmon Using NearInfrared Hyperspectral Imaging”, Spinger Link, vol. 7, no. 4, p. 12081214,2013
[10] R. Lu, Detection of bruise on apples using near-infrared hyperspectral imaging, Am. Soc. Agric. Eng., vol. 46, pp. 18, 2003.

[11] D. P. Ariana, R. Lu, and D. E. Guyer, "Near-infrared hyperspectral reectance imaging for detection of bruises on pickling cucumbers", Comput. Electron. Agric., vol. 53, pp. 6070, 2006.

[12] L. Karlinasari, M. Sabed, N. J. Wistara, and Y. A. Purwanto, "Karakteristik Spektra Absorbansi Nir (Near Infra Red) Spektroskopi Kayu Acacia Mangium Willd. Pada 3 Umur Berbeda", J. Ilmu Kehutan., vol. 5, pp. 4552, 2012.

[13] J. N. Arippin, A. Sutresno, and F. S. Rondonuwu, "Identifikasi Susu Sapi Urni Dan Susu Sapi Yang Mengandung Peroksida Dengan Spektroskopi Inframerah Dekat Dengan Teknik Pca", Pros. Semnar Nas. Sains Dan Pendidik. Sains IX Fak. Sains Dan Mat., vol. 5, pp. 193196, Jun. 2014.

[14] J. Rodgers and K. Beck, "NIR Characterization and Measurement of the Cotton Content of Dyed Blend Fabrics", Text. Res. J., vol. 79, pp. 675686 .

[15] H. Jiang, H. Zhuang, S. Miryeong, and W. Wang, "Measurement of Soy Contents in Ground Beef Using Near-Infrared Spectroscopy", vol. 7, pp. 19, 2017.

[16] J. W. Jr and L. Weyer, Practical Guide And Spectral Atlas For Interpretive Near-Infrared Spectroscopy. 2012.

[17] L. C. E. C. Lengkey, I. W. Budiastra, K. B. Seminar, and B. S. Purwoko, "Model Pendugaan Kandungan Air, Lemak Dan Asam Lemak Bebas Pada Tiga Provenan Biji Jarak Pagar (Jatropha Curcas L.) Menggunakan Spektroskopi Inframerah Dekat Dengan Metode Partial Least Square (Pls)", J. Littri, vol. 19, pp. 203211, 2013.

[18] G. ElMasry, D.-W. Sun, and P. Allen, "Chemical-free assessment and mapping of major constituents in beef using hyperspectral imaging”, Elsevier, vol. 117, no. 2, pp. 235246, 2013. 